\title{
Early Detection of Vasculogenic ED in Diabetic Patients by Assessment of Platelet Indices
}

\author{
Ahmed Ibrahim Elmenshawy ${ }^{1 *}$ MSc; Tarek Mohammed Tawfik ${ }^{1}$ MD; Hassan Mamdouh Abd Elaziz ${ }^{1}$ MD; \\ Nagah Mohamed A. Mohamed ${ }^{2}$ MD
}

*Corresponding Author:

Ahmed Ibrahim Elmenshawy amenshawy61@gmail.com

Received for publication October 27,2020;Accepted january 4, 2021; Published online january 4, 2021.

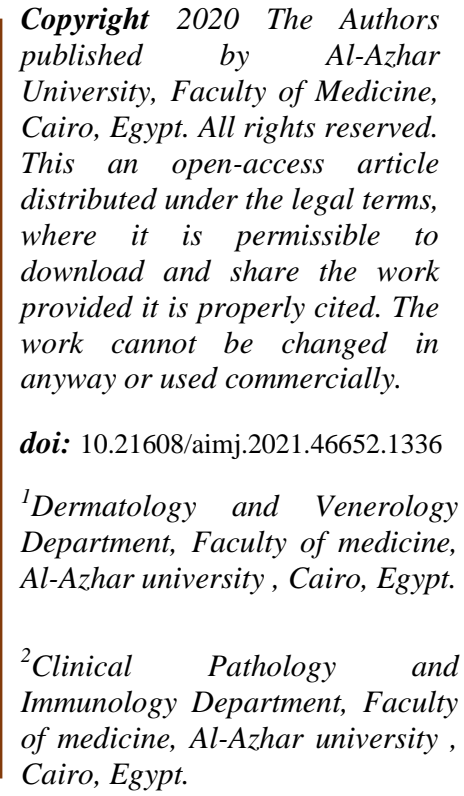

\section{INTRODUCTION}

Failure to obtain or sustain a satisfactory erection of the penile for sexual intercourse is erectile dysfunction (ED). ${ }^{1}$ Average prevalence of up to $10 \%$ in men aged less than 50 years; ED is a common global issue. In males aged 60-70 years, the incidence rises to $20 \%-40 \%$. The largest prevalence of men older than 70 years is $50 \%-100 \%$. $^{2}$

Diabetes mellitus (DM) has been shown to be substantially and independently related to erectile dysfunction. ${ }^{3}$ ED prevalence in patients with diabetes varies from $20 \%$ to $70 \%$, irrespective of the severity or length of the disease or the regulation of hyperglycaemia. ${ }^{4}$

Its etiology can be organic, psychogenic, or most commonly, derived from a combination of the two. ${ }^{5}$

In diabetic patients, ED aetiopathogenesis is complex and influenced by several psychological or organic factors. ${ }^{6}$ It is also recognised that age plays a part in
Disclosure: The authors have no financial interest to declare in ation to the content of this article. The Article Processing Charge was paid for by the authors.

Authorship: All authors have a substantial contribution to the article. 
regulated disease and in healthy non-diabetic people. $^{13}$

In recent years, there have been some studies which report that mean platelet volume (MPV) increases in patients with vasculogenic ED. ${ }^{14} \mathrm{MPV}$ is a platelet size marker that is readily measured and routinely accessible at relatively low prices by automated blood counters and reflects indirectly platelet activity. Since large platelets are metabolically and enzymatically more active than small platelets and generate more thromboxane, recognised as the most powerful vasoconstrictor agent, increasing the production of large platelets cab lead to the pathogenesis of atherothrombosis. Increased platelet activity therefore plays a significant role in the development of atherosclerosis via mechanisms such as thrombocyte collection, synthesis of tromboxane, and expression of adhesion molecules. ${ }^{15}$

\section{Subjects AND METHODS}

This research was performed on 90 persons divided into three groups (Group A) 30 diabetic male patients with ED were attended to Dermatology and Venerology department at Al-Azhar University Hospitals, (Group B) 30 diabetic male patients without ED and (Group C) 30 healthy individuals as control.

Patient with the following criteria was included in the study: heterosexual males below 75 years of age, existence of ED estimated by the International Index of Erectile Function (IIEF), ED patients investigated by penile dynamic Doppler, patients with diabetes mellitus. We excluded patients with the following criteria from the study: significant cardiac diseases, neurological diseases, major psychiatric disorders, pelvic trauma and operations, penile trauma and operations, hormonal disturbances affecting the sexual functions, using medicines which influence sexual function or sexual desire.

All patients have undergone a Full History including Sexual History, clinical examinations including genital examination and laboratory investigations: venous blood sample was taken for measurement of $\mathrm{CBC}, \mathrm{HbA} 1 \mathrm{c}$, and platelet indices.

In patients have ED wih DM (group A) investigated by Pharmaco-penile duplex ultrasonography (PPUD). It done to assessed the grade of erection following intracorporal injection (ICI) of prostaglandin E1 in one corpora cavernosa. Before and after ICI, the cavernous artery diameter was measured. Peak systolic flow velocity (PSV), end diastolic velocity (EDV) and resistance index (RI) were measured after ICI at 5, 10, and 15 minutes. The PSV has been graded as less than $25 \mathrm{~cm} / \mathrm{s}, 25-35 \mathrm{~cm} / \mathrm{s}$ and more than $35 \mathrm{~cm} / \mathrm{s}$. The EDV has been graded as $5 \mathrm{~cm} / \mathrm{s}$ or less and larger than $5 \mathrm{~cm} / \mathrm{s}$. The RI has been graded as $0.8 \mathrm{~cm} / \mathrm{s}$ or less and larger than $0.8 \mathrm{~cm} / \mathrm{s}$. Patients were divided into four groups according to the PPDU study: diabetic with arteriogenic ED, diabetic with venogenic $E D$, diabetic with mixed arteriovenogenic $\mathrm{ED}$ and diabetic with psychogenic $\mathrm{ED}$.

\section{Statistical analysis:}

The data was analyzed using version 18.0 of the Statistical Program for Social Science (SPSS). Mean \pm standard deviation (SD) was the quantitative data expressed. Qualitative data were represented in terms of frequency and percentage. P-value $<0.05$ was deemed significant (S), P-value $>0.05$ was deemed non-significant (NS).

\section{RESULTS}

The next table indicates that a statistically substantial differences between the three studied groups in term of age, weight and BMI with p-value $=0006,0.001$ and $<0.001$ respectively while no statistically substantial differences were found between the three studied groups in terms of height with $\mathrm{p}$-value $=$ 0.775 . The platelet count was statistically substantially decreased and increase in PDW, MPV, HbA1c and IIEF in ED with DM and DM without ED.

Table 1: Comparison among the three groups studied for demographic data and the laboratory for the cases

\begin{tabular}{|c|c|c|c|c|c|c|c|}
\hline & $\begin{array}{c}\text { ED with DM } \\
\text { group }\end{array}$ & $\begin{array}{l}\text { DM without } \\
\text { ED group }\end{array}$ & $\begin{array}{c}\text { Control } \\
\text { group }\end{array}$ & \multirow{2}{*}{$\begin{array}{c}\text { Test } \\
\text { value }\end{array}$} & \multirow[t]{2}{*}{ P-value } & \multirow[t]{2}{*}{ Sig. } \\
\hline & & No. $=30$ & No. $=30$ & No. $=30$ & & & \\
\hline Age & $\begin{array}{c}\text { Mean } \pm \text { SD } \\
\text { Range }\end{array}$ & $\begin{array}{c}55.10 \pm 8.32 \\
41-78\end{array}$ & $\begin{array}{c}52.73 \pm 9.82 \\
36-72\end{array}$ & $\begin{array}{c}46.67 \pm 12.15 \\
30-81\end{array}$ & 5.433 & 0.006 & HS \\
\hline Height & $\begin{array}{c}\text { Mean } \pm \text { SD } \\
\text { Range }\end{array}$ & $\begin{array}{c}168.13 \pm 6.22 \\
156-178\end{array}$ & $\begin{array}{c}168.03 \pm 7.85 \\
155-180\end{array}$ & $\begin{array}{c}166.97 \pm 6.87 \\
157-178\end{array}$ & 0.255 & 0.775 & NS \\
\hline Weight & $\begin{array}{c}\text { Mean } \pm \text { SD } \\
\text { Range }\end{array}$ & $\begin{array}{c}76.07 \pm 6.67 \\
67-93\end{array}$ & $\begin{array}{c}78.83 \pm 9.55 \\
59-98\end{array}$ & $\begin{array}{c}70.40 \pm 9.67 \\
56-93\end{array}$ & 7.259 & 0.001 & HS \\
\hline BMI & $\begin{array}{c}\text { Mean } \pm \text { SD } \\
\text { Range }\end{array}$ & $\begin{array}{c}26.89 \pm 1.47 \\
24.4-29.6\end{array}$ & $\begin{array}{c}27.83 \pm 1.69 \\
24.2-32\end{array}$ & $\begin{array}{c}25.22 \pm 2.81 \\
18.7-29.4\end{array}$ & 12.185 & 0.000 & HS \\
\hline Platelet & $\begin{array}{c}\text { Mean } \pm \text { SD } \\
\text { Range }\end{array}$ & $\begin{array}{c}295.43 \pm 58.71 \\
198-475\end{array}$ & $\begin{array}{c}332.17 \pm 62.34 \\
197-419\end{array}$ & $\begin{array}{c}350.23 \pm 57.07 \\
255-499\end{array}$ & 6.628 & 0.002 & HS \\
\hline PDW & $\begin{array}{c}\text { Mean } \pm \text { SD } \\
\text { Range }\end{array}$ & $\begin{array}{c}17.14 \pm 1.02 \\
15-18.7\end{array}$ & $\begin{array}{c}14.83 \pm 0.98 \\
12.9-17.2\end{array}$ & $\begin{array}{c}13.75 \pm 1.51 \\
11-16.4\end{array}$ & 62.717 & 0.000 & HS \\
\hline MPV & $\begin{array}{c}\text { Mean } \pm \text { SD } \\
\text { Range }\end{array}$ & $\begin{array}{c}10.72 \pm 0.84 \\
9-12.1\end{array}$ & $\begin{array}{c}9.19 \pm 0.89 \\
7.1-11.4\end{array}$ & $\begin{array}{c}7.89 \pm 0.97 \\
5.7-10\end{array}$ & 73.941 & 0.000 & HS \\
\hline $\mathrm{HbA} 1 \mathrm{C}$ & $\begin{array}{c}\text { Mean } \pm \text { SD } \\
\text { Range }\end{array}$ & $\begin{array}{c}9.08 \pm 1.56 \\
6.6-14.2 \\
\end{array}$ & $\begin{array}{c}7.28 \pm 1.35 \\
5.2-10.7 \\
\end{array}$ & $\begin{array}{c}5.47 \pm 0.82 \\
4.3-7.4\end{array}$ & 59.223 & 0.000 & HS \\
\hline IIEF & $\begin{array}{l}\text { Mean } \pm \text { SD } \\
\text { Range }\end{array}$ & $\begin{array}{l}12.13 \pm 4.12 \\
4.83-20.43\end{array}$ & $\begin{array}{l}- \\
-\end{array}$ & $\begin{array}{c}22.78 \pm 2.23 \\
18.30-25.16\end{array}$ & 12.451 & $<0.001$ & HS \\
\hline
\end{tabular}

The next table indicates that a statistically substantial reduction in platelet count and an increase in PDW, MPV and HbA1c in ED with DM than control group.

Table 2: Comparison of laboratory data among ED

\begin{tabular}{|c|c|c|c|c|c|c|}
\hline \multicolumn{2}{|c|}{} & $\begin{array}{c}\text { ED with DM } \\
\text { group }\end{array}$ & $\begin{array}{c}\text { Control } \\
\text { Group }\end{array}$ & $\begin{array}{c}\text { Test } \\
\text { value•- }\end{array}$ & P-value & Sig. \\
\cline { 3 - 7 } & No. = 30 & No. = 30 & & \\
\hline \multirow{2}{*}{ Platelet } & $\begin{array}{c}\text { Mean } \pm \text { SD } \\
\text { Range }\end{array}$ & $\begin{array}{c}295.43 \pm 58.71 \\
198-475\end{array}$ & $\begin{array}{c}350.23 \pm 57.07 \\
255-499\end{array}$ & $\begin{array}{c}- \\
3.666\end{array}$ & 0.001 & HS \\
\hline \multirow{2}{*}{ PDW } & $\begin{array}{c}\text { Mean } \pm \text { SD } \\
\text { Range }\end{array}$ & $\begin{array}{c}17.14 \pm 1.02 \\
15-18.7\end{array}$ & $\begin{array}{c}13.75 \pm 1.51 \\
11-16.4\end{array}$ & $\begin{array}{c}10.16 \\
3\end{array}$ & 0.000 & HS \\
\hline \multirow{2}{*}{ MPV } & $\begin{array}{c}\text { Mean } \pm \text { SD } \\
\text { Range }\end{array}$ & $\begin{array}{c}10.72 \pm 0.84 \\
9-12.1\end{array}$ & $\begin{array}{c}7.89 \pm 0.97 \\
5.7-10\end{array}$ & $\begin{array}{c}12.08 \\
2\end{array}$ & 0.000 & HS \\
\hline \multirow{2}{*}{ HbA1C } & $\begin{array}{c}\text { Mean } \pm \text { SD } \\
\text { Range }\end{array}$ & $\begin{array}{c}9.08 \pm 1.56 \\
6.6-14.2\end{array}$ & $\begin{array}{c}5.47 \pm 0.82 \\
4.3-7.4\end{array}$ & $\begin{array}{c}11.20 \\
6\end{array}$ & 0.000 & HS \\
\hline
\end{tabular}

with DM group and control group 
The next table indicates that a statistically substantial reduction in platelet count and an increase in PDW, MPV, and HbA1c in ED with DM group than DM without ED group.

\begin{tabular}{|c|c|c|c|c|c|c|}
\hline & $\begin{array}{c}\text { ED with DM } \\
\text { group }\end{array}$ & $\begin{array}{l}\text { DM without } \\
\text { ED group }\end{array}$ & \multirow{2}{*}{ Test value• } & \multirow{2}{*}{ P-value } & \multirow{2}{*}{ Sig } \\
\hline & & No. $=30$ & No. $=30$ & & & \\
\hline \multirow{2}{*}{ Platelet } & Mean \pm SD & $295.43 \pm 58.71$ & $332.17 \pm 62.34$ & \multirow{2}{*}{-2.350} & \multirow{2}{*}{0.022} & \multirow{2}{*}{$\mathrm{S}$} \\
\hline & Range & $198-475$ & $197-419$ & & & \\
\hline \multirow{2}{*}{ PDW } & Mean \pm SD & $17.14 \pm 1.02$ & $14.83 \pm 0.98$ & \multirow{2}{*}{8.912} & \multirow{2}{*}{0.000} & \multirow{2}{*}{ HS } \\
\hline & Range & $15-18.7$ & $12.9-17.2$ & & & \\
\hline \multirow{2}{*}{ MPV } & Mean \pm SD & $10.72 \pm 0.84$ & $9.19 \pm 0.89$ & \multirow{2}{*}{6.837} & \multirow{2}{*}{0.000} & \multirow{2}{*}{ HS } \\
\hline & Range & $9-12.1$ & $7.1-11.4$ & & & \\
\hline \multirow{2}{*}{$\mathrm{HbAlC}$} & Mean \pm SD & $9.08 \pm 1.56$ & $7.28 \pm 1.35$ & \multirow{2}{*}{4.756} & \multirow{2}{*}{0.000} & \multirow{2}{*}{ HS } \\
\hline & Range & $6.6-14.2$ & $5.2-10.7$ & & & \\
\hline
\end{tabular}

Table 3: Comparison among ED with DM group and DM without ED group regarding laboratory data

The next table indicates that a statistically substantial correlation observed among $\mathrm{HbAlc}$ and platelet count while the negative association among $\mathrm{HbAlc}$ and IIEF was statistically substantial, a statistically substantial positive association among HbA1c, PDW and MPV.

\begin{tabular}{|c|c|c|}
\hline \multirow{2}{*}{ ED with DM group } & \multicolumn{2}{|c|}{ HbA1C } \\
\cline { 2 - 3 } & $\mathbf{R}$ & P-value \\
\hline IIEF & $\mathbf{- 0 . 4 5 1}$ & $\mathbf{0 . 0 1 2}$ \\
\hline Platelet & 0.027 & 0.889 \\
\hline PDW & $\mathbf{0 . 4 7 5}$ & $\mathbf{0 . 0 0 8}$ \\
\hline MPV & $\mathbf{0 . 4 4 8}$ & $\mathbf{0 . 0 1 3}$ \\
\hline
\end{tabular}

Table 4: Correlation of HbA1c level and laboratory data in ED with DM group

The next table indicates that a statistically substantial negative correlation observed among IIEF and PDW and MPV and positive association with Platelet count.

\begin{tabular}{|c|c|c|}
\hline \multirow{2}{*}{ ED with DM group } & \multicolumn{2}{|c|}{ IIEF } \\
\cline { 2 - 3 } & $\mathbf{R}$ & P-value \\
\hline Platelet & $\mathbf{0 . 5 0 5}$ & $\mathbf{0 . 0 0 4}$ \\
\hline PDW & $\mathbf{- 0 . 4 0 2}$ & $\mathbf{0 . 0 2 7}$ \\
\hline MPV & $\mathbf{- 0 . 3 9 1}$ & $\mathbf{0 . 0 3 3}$ \\
\hline
\end{tabular}

Table 5: Correlation of IIEF level with laboratory data in ED with DM group

The next table indicates that a statistically substantial positive correlation observed among PSV and PDW and MPV and no statistically significant correlation with Platelet count.

\begin{tabular}{|c|c|c|}
\hline ED with DM group & \multicolumn{2}{|c|}{ PSV } \\
\cline { 2 - 3 } (Arteriogenic) & R & P-value \\
\hline Platelet & -0.101 & 0.700 \\
\hline PDW & $\mathbf{0 . 5 5 6}$ & $\mathbf{0 . 0 2 1}$ \\
\hline MPV & $\mathbf{0 . 5 6 4}$ & $\mathbf{0 . 0 1 8}$ \\
\hline
\end{tabular}

Table 6: Correlation between vasculogenic changes (PSV) by PPUD and Platelet Indices

\section{DISCUSSION}

Erection is a complicated event in which the vascular endothelium, smooth muscle bundles, autonomic nerves and extracellular matrix participate simultaneously. ${ }^{16}$
ED is predominant in patients with diabetes mellitus and those with disseminated vascular diseases, such as coronary and peripheral atherosclerosis; EDys may also be present in other vascular beds in men with penile vascular damage. ${ }^{17}$

The pathogenesis of endothelial dysfunction and ED is linked with reduced endothelial nitric oxide synthase (NOS) expression and activation, which is responsible for the production of Nitric Oxide (NO). Nitric oxide (NO) is a calming factor that plays a significant part in stimulating the erection process and sustaining it. ${ }^{18}$

Diabetic vasculopathy, which include micro- and macro-angiopathy and endothelial dysfunction, has an important part in having caused ED in DM by triggering atherosclerotic changes with a reduction in the flow of penile blood, a main factor in vascular $\mathrm{ED}^{8}{ }^{8}$

PPDU is the most commonly used examination for the diagnosis of vascular induced ED, but it is invasive and costly. ${ }^{19}$

Previous studies assumed that platelet and leukocyte adhesion has an adverse impact on erection through the release of vasoconstrictor substances and reactive oxygen species, and this could also play a part in the ED progress. ${ }^{20}$

PIs are popular indicators that are used to evaluate the activity and function of platelets. ${ }^{21}$

This study was conducted to measure the PIs of men with diabetes who have ED and to associate among PIs and ED and also to associate among PIs and vasculogenic ED

As regard the relation between three studies groups, showed a significant relation between platelet indices, ED and DM.

A statistically substantial increase was found in PIs (MPV, PDW) and HbA1C in group A (ED with DM) than group $\mathrm{B}$ (DM with out $\mathrm{ED}$ ) and group $\mathrm{C}$ (control group). A statistically substantial decrease was also reported in PIs (PC) in group A (ED with DM) than group B (DM with out ED) and group C (control group).

A statistically substantial difference was found among group A (ED with DM), group B (DM without $\mathrm{ED})$ and group $\mathrm{C}$ (control group) regarding age, weight and BMI

As regard PIs (MPV and PDW), there was a statistically substantial negative association among IIEF-5 score in group A (ED with DM) when compared with group C (control), so there has been a substantial increase in MPV and PDW with increased ED severity (decreased IIEF-5 score). A statistically substantial association was also found among PIs (MPV and PDW) with HbA1c.

A statistically substantial association was also found among PIs (MPV and PDW) and vasculogenic alteration as measured by the PPDU and nonsignificant within PIs (PC) that means increased of PIs (MPV and PDW) in vasculogenic ED. As regard $\mathrm{HbAlc}$, a statistically substantial negative relationship among HbA1c which represent 
glycaemic regulation and ED severity as per to the IIEF-5 score that means uncontrold diabetic patients have more sever ED.

As regard diabetes, there has been a statistically substantial rise in the PDW, MPV and HbAlc levels in DM without ED than control group.

In this research, a significant increase in PIs (MPV and PDW) in group A (ED with DM) than group B (DM without ED) and group $\mathrm{C}$ (control). A substantial association among ED and PIs (MPV and PDW) levels was found in patients, particularly in arterial, venous or mixed vasculogenic ED. Nevertheless, among PIs (PC) and vasculogenic ED, no substantial relationship was found. This implies that in diabetic men, levels of PIs (PC, MPV and PDW) rise with the intensity of ED.

The findings of the current study are in line with the research from El Taieb that was study the relationship among platelet indices and erectile dysfunction among men with diabetes and showed that platelet indices levels were substantially greater in ED patients with DM than in healthy men.2

In patients with vasculogenic ED, Ciftci and his colleagues found higher than normal levels of $\mathrm{PC}$ and MPV. They proposed that platelets can play a role in vascular complications pathogenesis, and MPV can assist in the assessment of disease progression. ${ }^{23}$

Bayraktar and his colleagues detected significantly higher MPV levels in ED than controls. ${ }^{24}$

As regard PIs in relation between group B (DM without $\mathrm{ED}$ ) and group $\mathrm{C}$ (control), the findings of the current study are in line with the study of Jindal that was done on 75 patients with type $2 \mathrm{DM}$ as the 'research group' and 50 non-diabetic patients as controls to evaluate diabetic versus non-diabetic platelet indices and to evaluate their usefulness as measures of the existence of complications in DM patients. They found that Platelet indices, particularly PDW, vary among diabetics and controls, and among diabetics with and without microvascular complications. ${ }^{25}$

Senturk and his colleagues detect non substantial difference in MPV values among patients and controls in their latest research (Can the early biomarkers for erectile dysfunction be platelets?). ${ }^{26}$

With regard to the association among $\mathrm{HbA} 1 \mathrm{c}$ and the ED severity, as per the IIEF-5 score, the findings of the present research were consistent with the Giugliano research, which evaluated the prevalence and correlations of ED in a population of males with diabetes in a total of 1290 patients (611 males and 659 females) and evaluated their utility as indicators of the glycemic regulation, as evaluated by $\mathrm{HbA} 1 \mathrm{c}$ level, was a danger factor for ED in males with diabetes. $^{27}$

$\mathrm{Lu}$ found that $\mathrm{HbA1c}$ levels were an important and independent danger factor for extreme ED relative to non- or mild-to-moderate $\mathrm{ED}$ in the Chinese population of 792 diabetic males. Guo and his colleagues proposed that to assess the intensity of ED, PDW could be used as a marker. A study on 358 ED patients demonstrated a relation among ED and platelet function, and PDW could possibly be monitored as a helpful marker for predicting the ED severity even when normal platelet counts and MPV values are noticed. $^{28}$

\section{CONCLUSION}

A significant association between platelet indices and ED In patients with diabetes with ED particularly those with vasculogenic pathology, PIs have increased. Our results suggest that PIs might as amarker for early ED diagnosis in men with diabetes In the future, PIs may be have an imbortant role for early diagnosis of ED especially vasculogenic ED.

\section{REFERENCES}

1. Ghanem HM, Salonia A and Martin-Morales A. SOP: physical examination and laboratory testing for men with erectile dysfunction. The journal of sexual medicine, 2013; 10(1):108-10.

2. Maiorino MI, Bellastella GB and Esposito K. Diabetes and sexual dysfunction; Current perspective. Diabetes, Metabolic Syndrome and Obesity: Target and Therapy, 2014; 7: 95-105.

3. Lu ZX, Walker KZ, O'Dea K, Sikaris KA and Shaw JE: HbA1C for screening and diagnosis of type 2 diabetes in routine clinical practice. Diabetes Care, 2010; 33: 817-9.

4. Penson DF and Wessells H. Erectile dysfunction in diabetic patients. Diabetes Spectrum, 2004; 17: 225 30 .

5. Lue TF. Erectile dysfunction, New England journal of medicine, 2000; 342(24):1802-13.

6. Kouidrat Y, Pizzol D, Cosco T, Thompson T, Carnaghi M, Bertoldo A and Veronese N. High prevalence of erectile dysfunction in diabetes: A systematic review and meta-analysis of 145 studies. Diabetic Medicine, 2017; 34(9): 1185-92.

7. Banks E, Joshy G, Abhayaratna WP, Kritharides L, Macdonald PS, Korda RJ and Chalmers JP. Erectile dysfunction severity as a risk marker for cardiovascular disease hospitalisation and all-cause mortality: A prospective cohort study. PLoS Medicine, 2013; 10: e1001372.

8. Esposito K, Giugliano F, Martedi E et al.: High proportions of erectile dysfunction in men with the metabolic syndrome. Diabetes Care, 2005; 28(5):1201-3.

9. Agrawal J, Singh VB, Meena B, Yadav R, Shareef M and Saini V. Mean paltelet volume (MPV) the neglected marker of cardiovascular risk and glycosylated hemoglobin in diabetic patient. Diabetes and Metabolic Syndrome: Clinical Research and Reviews, 2016; 11(2): 109-12.

10. Sansanayudh N, Anothaisintawee T, Muntham D, McEvoy M, Attia J and Thakkinstian A. Mean platelet volume and coronary artery disease: A systematic review and meta-analysis. International Journal of Cardiology, 2014; 175: 433-40. 
11. Sachdev R, Tiwari AK, Goel S, Raina V and Sethi M. Establishing biological reference intervals for novel platelet parameters (immature platelet fraction, high immature platelet fraction, platelet distribution width, platelet large cell ratio, platelet-X, plateletcrit, and platelet distribution width) and their correlations among each other. Indian Journal of Pathology and Microbiology, 2014; 57: 231-5.

12. Demirin H, Ozhan H, Ucgun T, Celer A, Bulur S and Cil $\mathrm{H}$. Normal range of mean platelet volume in healthy subjects: Insight from a large epidemiologic study. Thrombosis Research, 2011; 128: 358-60

13. Radha RK and Selvam D. MPV in Uncontrolled \& Controlled Diabetics Its Role as an Indicator of Vascular Complication, Journal of Clinical Diagnosis Research, 2016; 10(8): EC22-EC26.

14. Aldemir M, Akdemir F, Okulu E, et al.: Evaluation of blood platelet count and function in patients with erectile dysfunction. Andrologia, 2016; 48:189-92.

15. Dong JY, Zhang YH and Qin LQ. Erectile dysfunction and risk of cardiovascular disease: Metaanalysis of prospective cohort studies. J Am Coll Cardiol, 2011; 58, 1378-1385.

16. Costa $\mathrm{C}$ and Virag R. The endothelial-erectile dysfunction connection: an essential update; J Sex Med, 2009; 6: 2390-404.

17. Kaiser DR, Billups K, Mason C, Wetterling R and Lundberg JL: Impaired brachial artery endotheliumdependent and -independent vasodilation in men with erectile dysfunction and no other clinical cardiovascular disease, J Am Coll Cardiol, 2004; 43: 179-84.

18. Aversa A, Roberto B, Davide F, Marco N, Pietro G and Giovanni S. Endothelial dysfunction and erectile dysfunction in the aging man; International Journal of Urology, 2010; 17:38-47.

19. Jones RW and Gingell JC: The vascular system and erectile dysfunction in diabetes-The role of penile Doppler. The British Journal of Diabetes and Vascular Diseases, 2002; 2: 263-5.
20. Jeremy JY, Angelini GD, Khan M, Mikhailidis DP, Morgan RJ, Thompson CS and Naseem KM. Platelets, oxidant stress and erectile dysfunction: An hypothesis. Cardiovascular Research, 2000; 46:50-4.

21. Bath P, Algert C, Chapman N, Neal B and Progress Collaborative Group: Association of mean platelet volume with risk of stroke among 3134 individuals with history of cerebrovascular disease. Stroke, 2004; 35: 622-6.

22. El Taieb MA, Hegazy EM, Maklad SM and Khairy R. Platelet Indices as a marker for early prediction of erectile dysfunction in diabetic patients. Andrologia, 2018; 51(1):e13163.

23. Ciftci H, Yeni E, Demir M, Yagmur I, Gümüs K and Celik H. Can the mean platelet volume be a risk factor for vasculogenic erectile dysfunction? World Journal of Men's Health, 2013; 31: 215-9.

24. Bayraktar Z and Albayrak S: Blood platelet activity in men with vasculogenic erectile dysfunction. Archives of Italian Urology and Andrology, 2017; 31(89): 51-4.

25. Jindal S, Gupta S, Gupta R, Kakkar A, Singh HV, Gupta $\mathrm{K}$ and Singh S. Platelet indices in diabetes mellitus: indicators of diabetic microvascular complications. Hematology, 2013; 16(2):86-9.

26. Senturk AB, Yaytokgil M, Yilmaz AH, Ekici M, Aydin C, Demir E and Cakiroglu B. Can platelets be the early biomarkers of erectile dysfunction? Journal of Pakistan Medical Association, 2018; 68(4): 515-8.

27. Giugliano F, Maiorino M, Bellastella G, Gicchino M, Giugliano D and Esposito K. Determinants of erectile dysfunction in type 2 diabetes. International Journal of Impotence Research, 2010; 22(3): 204-9.

28. Guo LQ, Liu YQ, Sun WD, Yuan MZ, Xiao ZY and Song HB: Significance of platelet distribution width as a severity marker of erectile dysfunction. Andrologia, 2017; 49: e12628. 